\title{
Determination of the optimal replacement content of Portland cement by stone powder using particle packing methods and analysis of the influence of the excess water on the consistency of pastes
}

\section{Determinação do teor ótimo de substituição do cimento Portland por pó de pedra usando métodos de empacotamento de partículas e análise do excesso de água na consistência de pastas}

H. F. CAMPOS a

heloisacampos@ufpr.br https://orcid.org/0000-0002-9597-0231

T. M. S. ROCHA a thaisamsrocha@yahoo.com.br https://orcid.org/0000-0002-8586-6449

G. C. REUS

gio reus@yahoo.com.br https://orcid.org/0000-0003-0443-4773

N. S. KLEIN a

nayaraklein@ufpr.br https://orcid.org/0000-0002-7905-9608

J. MARQUES FILHO

Abstract jmarquesfilho@gmail.com

Cement is considered the basic component with the highest environmental impact in construction, in terms of $\mathrm{CO}_{2}$ emissions. As for the aggregates, the process of comminution of rocks, in addition to artificial sand, generates stone powder that ends up being stored outdoors, generating environmental damages. Thus, the replacement of cement by stone powder appears as an attractive alternative towards the sustainable concretes. In this context, the objective of this paper is to determine the maximum packing density in Portland cement, silica fume and stone dust pastes, to determine the optimal cement substitution content for the stone powder. In addition, it is intended to verify the influence of excess water on the consistency of the mixtures produced. The substitution was done in contents equal to $0 \%, 7 \%, 14 \%$ and $21 \%$ by volume and, for each content, the packing density was determined analytically by CPM model and combinations were reproduced experimentally. Excess water was checked by the mini Kantro cone test. The results showed that the higher cement substitution content of the stone powder obtained the higher packing density, experimental and analytical, and the higher workability, allowing economic and environmental advantages. Analyzing each material, the stone powder resulted in the highest packing density and silica fume is the lowest one. Therefore, finer particles resulted in lower packaging densities, due to the greater specific surface area, which demands more water. The agglomeration resulted in more empty gaps between the grains. In addition, mixtures flowability increased with the increase of the stone powder content. As the excess water is responsible for mixture lubrication, a higher packing density for a given volume of water improves the flowability.

Keywords: stone powder, cement paste, particle packing, excess water, sustainability.

\section{Resumo}

O cimento Portland é considerado o componente de base com o maior impacto ambiental na construção civil, em termos de emissões de $\mathrm{CO}_{2}$. Quanto aos agregados, o processo de cominuição das rochas, além da areia artificial, gera pó de pedra que acaba sendo armazenado ao ar livre, gerando impactos ambientais. Assim, a substituição do cimento por pó de pedra aparece como uma alternativa atraente em direção à dosagem de concretos sustentáveis. Nesse contexto, o objetivo do presente trabalho é determinar a máxima densidade de empacotamento de partículas em pastas compostas por cimento Portland, sílica ativa e pó de pedra, buscando determinar o teor ótimo de substituição do cimento pelo pó de pedra. Além disso, pretende-se verificar a influência do excesso de água na consistência das pastas produzidas. A substituição do cimento por pó de pedra foi feita em teores iguais a $0 \%, 7 \%, 14 \%$ e $21 \%$, em volume, sendo determinada a densidade de empacotamento analiticamente, pelo modelo CPM. As combinações foram reproduzidas experimentalmente. A consistência das pastas foi verificada com auxílio do mini cone de Kantro. Os resultados demonstraram que o maior teor de substituição do cimento pelo pó de pedra apresentou a maior densidade de empacotamento, experimental e analítica, e a maior trabalhabilidade, permitindo vantagens econômicas e ambientais. Analisando cada material individualmente, o pó de pedra apresentou a maior densidade de empacotamento e a sílica ativa a menor. Partículas finas resultam em menor densidade de empacotamento, devido à maior superfície específica, a qual demanda mais água. A aglomeração aumenta os vazios entre os grãos. Além disso, a fluidez das pastas produzidas aumentou com o acréscimo do teor de pó de pedra. Como o excesso de água é o responsável pela lubrificação da pasta, uma densidade de empacotamento mais elevada colabora para o aumento da fluidez quando o volume de água permanece fixo.

Palavras-chave: pó de pedra, pasta de cimento, empacotamento de partículas, excesso de água, sustentabilidade. 


\section{Introduction}

Sand natural extraction is responsible for vegetal cover removal, water courses degradation and environmental damage, which makes it difficult to obtain environmental licenses for new deposits $[1 ; 2 ; 3 ; 4]$. The environmental impact resulting from this material uses is further aggravated by informality in the extraction processes $[1 ; 5 ; 6]$. The replacement of natural sand by small crushing aggregate, can be an attractive alternative $[1 ; 2 ; 3 ; 7 ; 8]$. However, artificial sand washing generates stone powder, characterized by material passing through the \# $200(0.075 \mathrm{~mm})$ sieve. This material stored in quarries causes changes in the landscape, obstructing drainage channels due to its deposition and dust generation in crushing operations. Using the stone powder from deposits, besides bringing greater profitability to companies, brings benefits to environment [6]. The use of stone powder in concrete blend reduces the cement consumption and consequently reduces the disposal of harmful materials to the enviroment.

Several studies have been carried out with the aim of incorporating stone powder into conventional concretes, increasing and/or replacing fine aggregate [8; 9]. The partial Portland cement replacement is another strategy that can be adopted in the attempt to incorporate the stone powder into concretes. This material production represents about 5 and $7 \%$ of anthropogenic $\mathrm{CO}_{2}$ emissions worldwide [10], which are due to consumption of fossil fuels and to decomposition of limestone, since it is made up of $44 \% \mathrm{CO}_{2}$ [5]. In national industry, the $\mathrm{CO}_{2}$ emission of the cement is around $600 \mathrm{kgCO}_{2} / \mathrm{t}$, [11]. Considering the well-established association between $\mathrm{CO}_{2}$ emissions and environmental changes, especially global warming, there is a continuing socio-environmental need to reduce industrial $\mathrm{CO}_{2}$ emissions.

Thus, conciling the need to reduce cement consumption in concrete with the use of crushing waste, such as stone powder, is an eco friendly alternative. It should be noted, however, that the stone powder is an inert material with a grain size greater than cement $[4 ; 8]$, which makes it difficult to use this residue in obtaining higher resistances. Therefore, Portland cement replacement studies by stone powder are more common in conventional concretes [8; 9]. To compensate strength loss associated with the stone powder use, silica fume is an option that could enable stone powder use in the production not only of conventional concrete, but also of high strength concrete, increasing the use options of this residue.

It is important to determine the appropriate proportion of each material in the mixtures, so pases, mortars and concretes are technically efficient. Particle packing methods can help achieve this goal. The particle packing of a blend is promoted by grain sizes distribution of its components and defines the rheological material properties [12]. As packing density increases, it is possible to obtain, in addition to a higher fluidity, a reduction in consumption of binder fluid to fill the gaps between the grains. In case of concrete, the cement paste can be considered as a fluid that acts as a binder between aggregates grains. This reduction in paste consumption contributes to lower shrinkage and creep and, consequently, a more resistant, durable and eco friendly concrete [13; 14]. In case of pastes, water is the fluid that provides mobility to Portland cement particles and to mineral additions, so that an efficient fine particles packaging results in a reduction in mixtures water consumption, and increases its fluidity.

This work aims to determine the maximum packing density of particles in Portland cement, silica fume and stone dust pastes, in order to determine the optimal cement substitution content for stone powder. In addition, it is intended to verify the influence of excess water on the consistency of the pastes produced.

\section{Bibliographic review}

Fine particle packing density determination is a challenge, due to the agglomeration of these particles, so that they are sensitive to compaction energy adopted, the presence of water and plasticizing and superplasticizing additives. Therefore, when it is desired to determine fine particles packing density that will be incorporated into mortars and concretes, it is not recommended to use experimental methods that consider the materials in the dry condition. This is because the results obtained will not represent the reality of the mixtures, which present water in its composition and can also count on the presence of additives. The packing density of the dry materials will differ from the density found when the materials are part of the mortar and concrete mixtures. Other experimental methods recommend linking packing density to consistency tests. These are also not efficient, because although they allow to consider the presence of water and additives in the mixtures, the consistency chosen to determine the packing density is arbitrarily defined, and the grains can be presented in different saturation conditions, depending on the value of consistency. Furthermore, the air content in the blends is often neglected by these methods, resulting in underestimation of void index and overestimation of packing density [14; 15].

Wong and Kwan [14] proposed a new experimental method, which can be adapted to different compaction conditions, allowing water, additives and air consideration in the blends. This experimental method, adopted in the present work, will be detailed below, in item 2.1.

In addition to experimental methods, predictive models can also be adopted in the search for values representative of the packing density of particles. Some models, such as the CPM model, proposed by De Larrard [16], present good precision in found results. This model defines granular assemblies packing density from the granulometric distribution and allows to consider the type of compaction applied. It also allows to consider aspects such as grain morphology, presence of water and additives in an indirect way, since it demands to know the packing density of each class of grains component of the mixtures, parameter that must be determined experimentally. The CPM analytical model, adopted in this paper, will be detailed in the continuation, in item 2.2.

\subsection{Experimental method of packing density}

A packing density of the dried particles was determined experimentally according to the method proposed by Wong and Kwan [14]. This method consists in dosing materials by varying water/solids ratio $(\mathrm{w} / \mathrm{s})$ and determining void index and solids concentration of each mixture through apparent density. This is done determining 


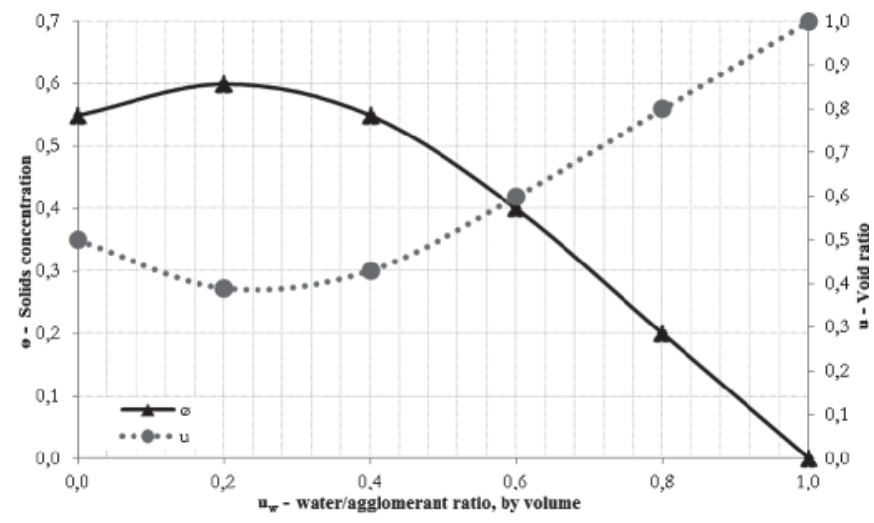

Figure 1

Typical graph obtained packing density determination test in wet condition, adapted from $[14 ; 37]$

the mass of a known volume of paste, where the vessel is commonly used to determine the specific mass of mortars. Void ratio and solids concentration of each mixture are calculated, according to equations (1) to (3).

$V_{s}=\frac{M}{\rho_{w} u_{w}+\sum_{i=1}^{n} \rho_{i} R_{i}}$

$\mathrm{u}=\frac{\left(\mathrm{V}-\mathrm{V}_{\mathrm{c}}\right)}{\mathrm{V}_{\mathrm{c}}}$

$\varnothing=\frac{V_{c}}{V}$

Where:

$\mathrm{V}_{\mathrm{s}}$ : fine materials solids volume present in the pastes;

M: paste mass filling the container for determination of bulk density;

$\mathrm{V}$ : vessel volume for bulk density determination;

$\rho_{\mathrm{w}}$ : water specific mass;

$\mathrm{u}_{\mathrm{w}}: \mathrm{w} / \mathrm{s}$ ratio, by volume;

$\rho_{\mathrm{i}}$ : material i specific mass;
$\mathrm{R}_{\mathrm{i}}$ : material i volume in relation to total solids volume u: void ratio;

$\Phi=$ solids concentration.

By means of equation (2), voids ratio is ratio between void volume and solids volume in blend, while equation (3) shows that solids concentration is the ratio between solids volume and the total paste volume present in the vessel used for performing the test. It should be noted that the results obtained for void ratio and solids concentration are associated with grains dispersion condition in the mixtures. To illustrate this association, we present a typical graph obtained by performing this experiment in Figure 1.

Figure 1 shows that when the w/s ratio is high, void ratio is also high, while the solids concentration in the blend is low. This occurs because the particles of the system are dispersed in water, as shown in Figure 2a, being spaced apart from each other by being surrounded by water. As w/s ratio is decreased, dispersed particles approach each other, so that the void ratio decreases and solids concentration increases progressively. This occurs until the condition is reached where void ratio is minimal and solids concentration is maximal. In this situation, particles are still surrounded by water, but the water is only sufficient to wet the grains, with air pores inside the mixture. It is observed that the solid particles are in contact with each other, as shown in Figure $2 \mathrm{~b}$, so that it is possible to associate this condition of maximum solids concentration with blend packing density. At this point, if the w/s ratio is again decreased, the water volume in the mixture will not be sufficient to completely envelop the solid particles, so that the water will concentrate at the points of contact between the grains. This causes there to be some distance between particles, as shown in Figure 2c, so that void ratio increases and solids concentration decreases [17; 18; 19]. It should be noted that the test also allows to determine, at the point of maximum solids concentration, the minimum water amount required for the mixture to form a homogeneous paste.

\subsection{Particle packing model - CPM}

The CPM model (Compressible Packing Model), proposed by De

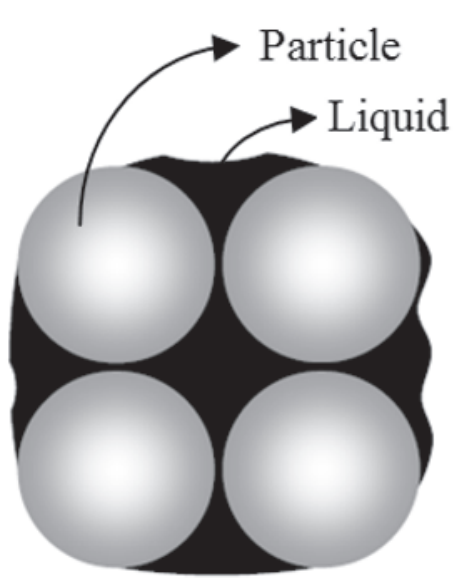

(a)

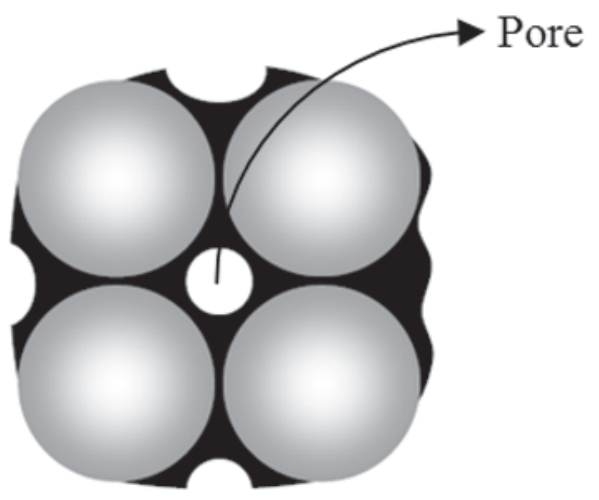

(b)

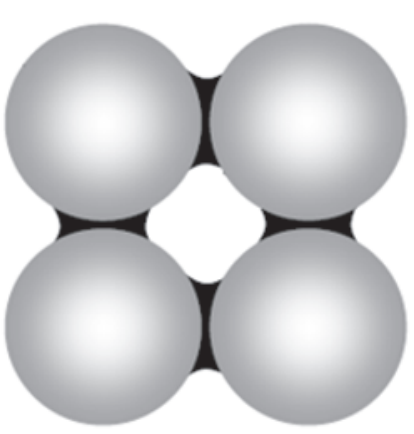

(c)

Figure 2

Particle dispersion conditions in water [adapted from 19] 


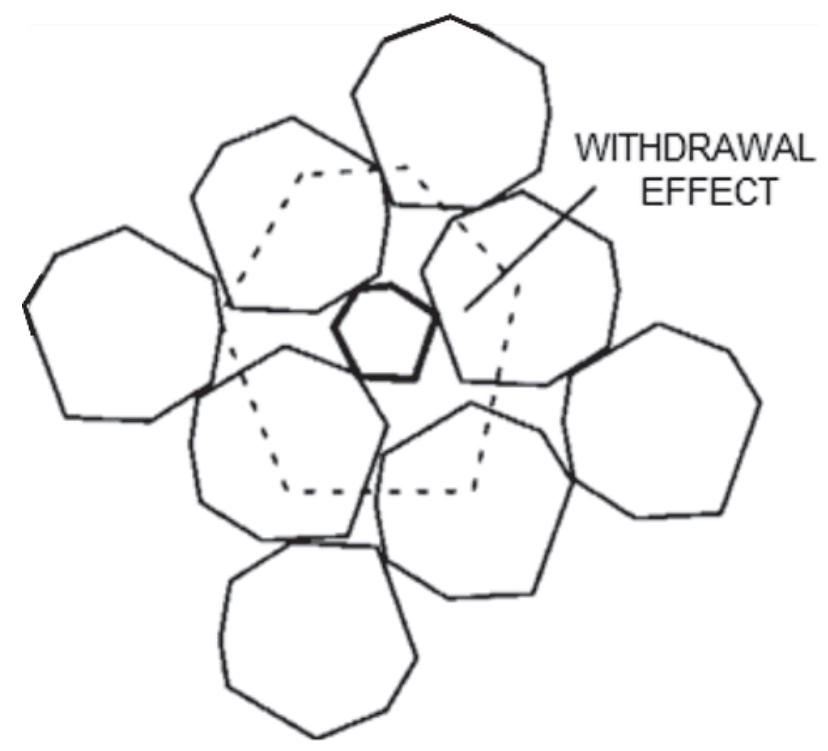

Figure 3

Withdrawal effect (adapted from [16])

Larrard (1999) [16], aims to predict packing density of polydisperse mixtures. This model is based on three parameters:

- The size of component grain of each class of set, described in granulometric curves of materials;

- The grains shape, considered indirectly from packaging density of each individual class;

- The method of packaging performing, or the compaction method used in mixtures processing.

With this model is possible to obtaining the smallest value for virtual packaging density $\gamma$, through equation (4), where $\beta_{i}$ and $\beta_{i}$ are the packing densities of each class and $y_{j}$ is material volume of each class.

$$
\gamma_{i}=\frac{\beta_{i}}{1-\sum_{j=1}^{i-1}\left[1-\beta_{i}+b_{i j} \times \beta_{i}\left(1-\frac{1}{\beta_{j}}\right)\right] \times y_{j}-\sum_{j=i+1}^{n}\left[1-a_{i j} \times \frac{\beta_{i}}{\beta_{j}}\right] \times y_{j}}
$$

The model also depends on withdrawal effect $a_{i j}$ and wall effect $b_{i j}$ values, as presented in equations (5) and (6). These effects consider the grains interaction. Withdrawal effect occurs when a larger grain is introduced between the larger particles than the existing empty gap, producing the effect of distancing larger grains (Figure 3). The wall effect occurs when a larger particle is inserted between the smaller dominant particles. The larger grain wall will prevent the smaller particles from approaching in this area, thereby reducing the volume of solids in region (Figure 4) [16].

$\mathrm{a}_{\mathrm{ij}}=\sqrt{1-\left(1-\frac{\mathrm{d}_{\mathrm{j}}}{\mathrm{d}_{\mathrm{i}}}\right)^{1,02}}$

$\mathrm{b}_{\mathrm{ij}}=1-\left(1-\frac{\mathrm{d}_{\mathrm{i}}}{\mathrm{d}_{\mathrm{j}}}\right)^{1,50}$

Finally, when considering compaction method used in processing granular mixture it is possible to obtain the actual packing density $\Phi$. This is done by coefficient $K$ as given by equation (7). The model author presents a study that assigns different values to $K$ associating these values to the most commonly used compaction methods in the processing of mixtures of pastes, mortars and concretes [16].

$\mathrm{K}=\sum_{\mathrm{i}=1}^{\mathrm{n}} \frac{\frac{\mathrm{y}_{\mathrm{i}}}{\beta_{\mathrm{i}}}}{\frac{1}{\Phi}+\frac{1}{\gamma_{\mathrm{i}}}}$

\section{Materials e method}

\subsection{Materials}

Portland cement, stone powder and silica fume were used for pastes production. Silica fume was incorporated in order to compensate for possible losses of resistance associated to the stone powder use, considering application of this study results for future concretes production, including high strength concretes. It was used stone powder and silica fume in addition to Portland cement. Silica fume has fine, rounded particles, recommended to achieve a higher packing density. The densification is obtained by particles in general 100 times smaller than as cement [20]. Silica fume dosages are usually between 5 and $15 \%$ of mass of cement. Values above that lead to considerable increases in concrete final cost and lower strength gain $[20 ; 21 ; 22 ; 23 ; 24]$.

Was added $8 \%$ of silica fume in fines mass, which is equivalent to $11 \%$ in volume. This value was defined in previous studies [6;25]. Portland cement type ARI (high initial strength) - V was used, which complies with specifications of standard NBR 5733 [26]. Stone powder was obtained by crushing the artificial sand from limestone suspended in water. The material was collected and then oven dried in laboratory at $60{ }^{\circ} \mathrm{C}$. Table 1 shows the specific masses and average

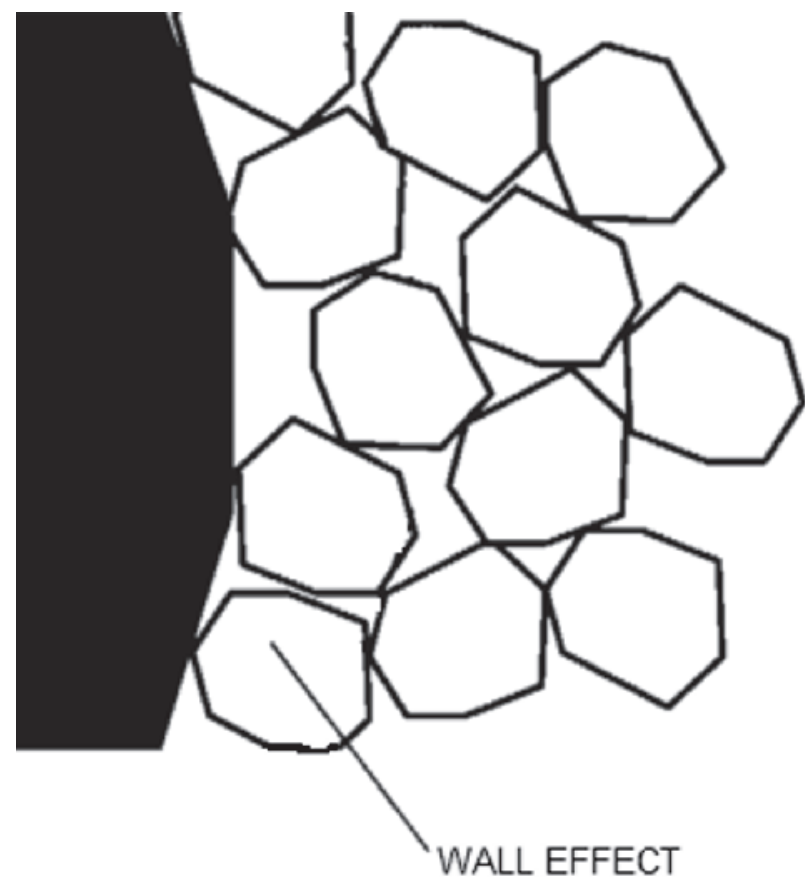

Figure 4

Wall effect (adapted from [16]) 


\section{Table 1}

Physical characteristics of cement, silica fume and stone powder

\begin{tabular}{cccc}
\hline \multicolumn{3}{c}{ Physical characteristics } \\
\hline Parameters & Cement & Silica fume & Stone powder \\
\hline $\begin{array}{c}\text { Specific mass } \\
\left(\mathrm{kg} / \mathrm{m}^{3}\right)\end{array}$ & 3,000 & 2,200 & 2,670 \\
$\begin{array}{c}\text { Average } \\
\text { diameter } \\
(\mu \mathrm{m})\end{array}$ & 7.97 & 0.2 & 40.43 \\
\hline
\end{tabular}

diameters of three materials. The chemical additive consists of a third generation superplasticizer based on modified carboxylic ether polymers. It should be noted that it meets the requirements of NBR 11768 [27] and its specific mass is equal to $1.100 \mathrm{~kg} / \mathrm{m}^{3}$, given by supplier. As the objective of this work is to analyze the influence of cement replacement by the stone powder, Figure 5 presents the granulometric curve of two materials obtained by the granulometric laser distribution. The equipment consists of a laser granulometer brand CILAS, model 1064. It was used as dispersion isopropyl alcohol and 1 minute of ultrasound. It is observed that cement is thinner than stone powder, and stone powder has a wider particle size range. Comparing three materials average diameter (Table 1), silica fume is the thinnest one, resulting in characteristic material filler effect.

\subsection{Method}

\subsubsection{Determination of additive content and packing density} of individual fines

The superplasticant (SP) saturation point determination was

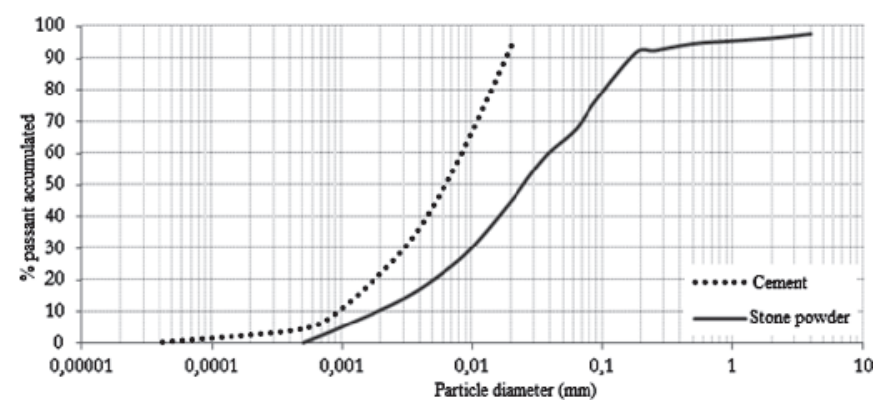

Figure 5

Granulometric distribution of cement and stone powder performed for each thin material. The tests performed were the mini Kantro cone [28] and Marsh cone [29]. In additive analysis content, for Portland cement and for stone powder, the w/s ratio was defined as 0.3 . Pilot tests were performed varying the relation w/s in the contents: $0.2 ; 0.3 ; 0.4 ; 0.5$, and the content 0.3 presented folders with adequate consistency for carrying out the tests. The contents of SP tested were: $0.3 \%, 0.6 \%, 0.9 \%, 1.2 \%$ and $1.5 \%$, relative to cement mass. Pastes produced without the additive did not provide the necessary fluidity for carrying out the tests and with $1.5 \%$ led to excess SP. However, for the silica fume, the runs were performed with the w/s ratio of 0.4 to 1 and the SP content of $0 \%$ to $3 \%$.

\subsubsection{Fine materials packing density determination}

The test for packing density determination consists in application of method proposed by [14], which provides pastes with different $\mathrm{w} / \mathrm{s}$ ratios for each material. The pastes were composed of solid material, water and additive.

Table 2 presents mortar materials mixing procedure. It will be seen that initially $50 \%$ of thin material, $80 \%$ of water and $80 \%$ of superplasticizer additive were added to mortar, then the mixture was made at low speed for 3 minutes. The remaining amounts of each material, $50 \%$ of fine material, $20 \%$ of water and $20 \%$ of SP were fractionated into four equal parts and added in mortar at different times. After each material addition, the paste was blended at low speed for 2 minutes. At the end of the process, all of materials had been added to the blend, which was carried out in a total time of 11 minutes.

After the mixing step, the pastes density were determinated in a $400 \mathrm{ml}$ cylindrical mold. The mold was filled in three layers of each paste, each layer compacted with 30 mallet strokes.

\subsubsection{Optimum Portland cement and stone powder ratio in pastes}

The blend optimum ratio among studied thine materials was determined from CPM method, proposed by [16]. Portland cement replacement by stone powder was done in contents equal to $0 \%, 6 \%, 12 \%$ and $18 \%$, by mass, which is equivalent to substitution percentages equal to $0 \%, 7 \%, 14 \%$ and $21 \%$ by volume. The literature indicates that higher values excessively increase water demand $[6 ; 30 ; 31 ; 32]$. The percentage of silica fume remained constant, as previously described, equal to $11 \%$ by volume. For each cement substitution contents per stone powder, packing density was determined analytically by CPM model. The input parameters for this model are

\section{Table 2}

Procedure for mixing the pastes - adapted from [19]

\begin{tabular}{cccc}
\hline Mixing step & Materials & Mixing time & Velocity \\
\hline $1^{a}$ & $50 \%$ Solid $+80 \%$ Water $+80 \%$ SP & 3 min. & Low \\
$2^{a}$ & $12.5 \%$ Solids $+5 \%$ Water $+5 \%$ SP & 2 min. & Low \\
$3^{a}$ & $12.5 \%$ Solids $+5 \%$ Water $+5 \%$ SP & 2 min. & Low \\
$4^{a}$ & $12.5 \%$ Solids $+5 \%$ Water $+5 \%$ SP & 2 min. & Low \\
$5^{a}$ & $12.5 \%$ Solids $+5 \%$ Water $+5 \%$ SP & 2 min. & Low \\
\hline
\end{tabular}


Table 3

Variables applied in CPM method (by volume)

\begin{tabular}{cccc}
\hline Variable & Cement & $\begin{array}{c}\text { Stone } \\
\text { powder }\end{array}$ & $\begin{array}{c}\text { Silica } \\
\text { fume }\end{array}$ \\
\hline $\begin{array}{c}\text { Volumetric } \\
\text { fraction }\end{array}$ & $0.89 ; 0.82 ;$ & $0 ; 0.7 ;$ & 0.11 \\
$\begin{array}{c}\text { Particle } \\
\text { diameter } \\
(\mu \mathrm{m})\end{array}$ & 7.97 & $0.14 ; 0.21$ & \\
\hline
\end{tabular}

presented in Table 3. For model application, the contents of each material are analyzed in volume. The $\mathrm{K}$ value used in method was 6.7, corresponding to wet compaction.

In order to compare the results obtained using the CPM model and to determine the optimum w/s ratio for mixtures of materials, the combinations were also reproduced experimentally. Density and packing were determined according to the method proposed by [14]

\subsubsection{Influence of excess water on the consistency of pastes}

Was tried to evaluate the influence of excess water on cement pastes consistency produced with replacement of Portland cement by stone powder at the same levels previously evaluated. The superplasticizer content used in mixture of three materials of $0.9 \%$, in relation to the total fines. This additive content was the highest found, except the silica fume, which presented a very high superplasticizer demand. More detailed explanations about the choice of the saturation point to be used are given in item 4.1. The silica fume content was the same used in experimental analysis of fine materials packing density. Considering then that experimental packing density is obtained in pastes whose water demand is the minimum required to wet grain components of mixture [9; 17], it is possible to calculate the volume of excess water. This is equal to the difference between water total volume used in mixtures (value used in mixtures that passed at consistency test) and the volume corresponding to minimum water demand. For paste consistency tests, the amount of water was pre-established for blend without

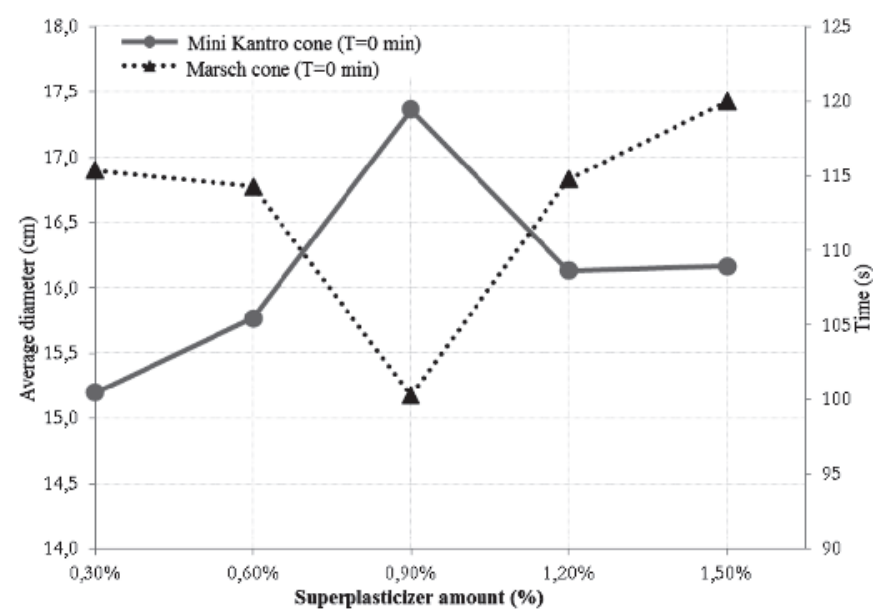

Figure 6

Results of cement and SP compatibility in mini Kantro cone and Marsh cone stone powder, w/s ratio was defined as 0.3 mass. The w/s ratio was kept constant for other mixtures. Thus, varying only substitution content of Portland cement by stone powder, it was possible to analyze the influence on consistency for the same relation w/s. The method used for consistency analysis of binders produced was mini cone of Kantro [28].

\section{Results and discussion}

\subsection{Superplasticizer additive saturation point}

The pastes produced without superplasticizer additive did not provide the fluidity required for the tests for all thin materials studied. The results of additive saturation point with cement obtained in mini Kantro cone and Marsh cone are shown in Figure 6.

It is observed in Figure 6 that the slump obtained in mini Kantro cone, with the pastes produced in three times, increased until the content of $0.9 \%$ of additive. Therefore, $0.9 \%$ of additive is the optimal content. When comparing the curves obtained at different times it is possible to verify that abatements decrease with time, which was expected due to the beginning of cement hydration process and loss of additive efficiency. It is observed in the Marsh cone curves that until the content of $0.9 \%$ of SP has times reduced, which highlights the greater fluidity of pastes produced with this content. Comparing the curves at different ages, there is an increase in time, which proves the previous conclusions.

Figure 7 shows additive saturation point results with the stone powder, by mini Kantro cone and Marsh cone tests.

It is observed in Figure 7 that slump obtained in mini Kantro cone increased significantly when uperplasticizer content was increased from $0.3 \%$ to $0.6 \%$. For higher contents of the additive, no significant increase of the scattering was observed when performing the mini Kantro cone test. Likewise, Marsh cone tests show a significant reduction in paste flow time increasing the additive content from $0.3 \%$ to $0.6 \%$. The same was not observed for higher contents, since flow times were slightly higher than that found for the

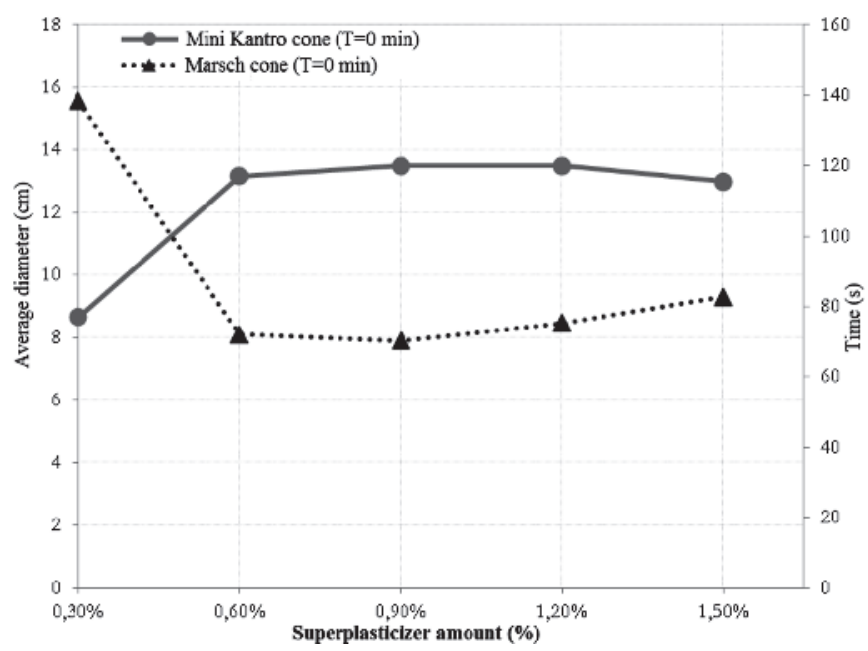

Figure 7

Results of stone powder and SP compatibility in mini Kantro cone and Marsh cone 

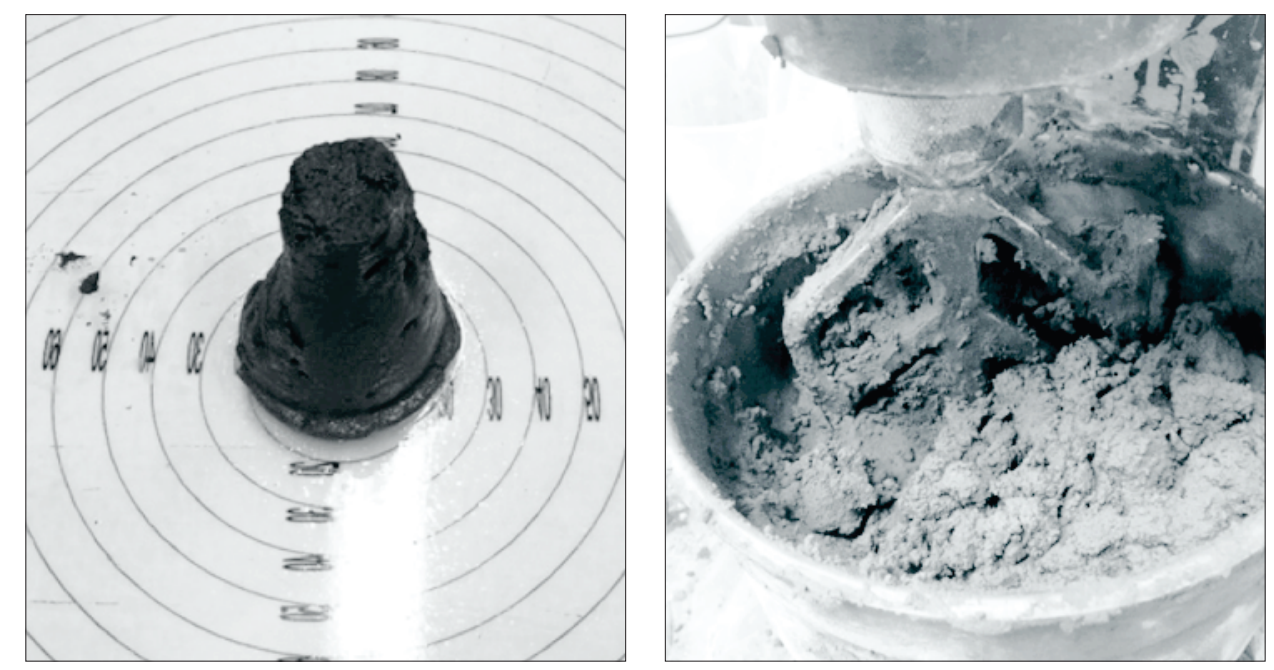

\section{Figure 8}

Silica fume pastes in the highest water and SP content

additive content equal to $0.6 \%$. This result was already expected, since stone powder is a thicker material than Portland cement (see Table 1). Consequently, it has a smaller specific surface to be covered by additive compared to the cement, which results in a lower saturation point.

As for silica fume, it was not possible to maintain the relation a / $\mathrm{s}$ and the SP content used in cement and stone powder. Silica fume has a much higher specific surface area than cement and stone powder, resulting in increased water demand.

For silica fume, superplasticizer additive content was gradually increased until a value of $3 \%$ was reached, and yet the mixture was not flowable. Figure 8 illustrates this situation. That is, with $3 \%$ additive the paste did not flow through Marsh cone and there was no opening through mini Kantro cone, leaving the opening diameter with cone measure itself. This $3 \%$ value is a high percentage of additive, since the manufacturer's maximum recommendation is

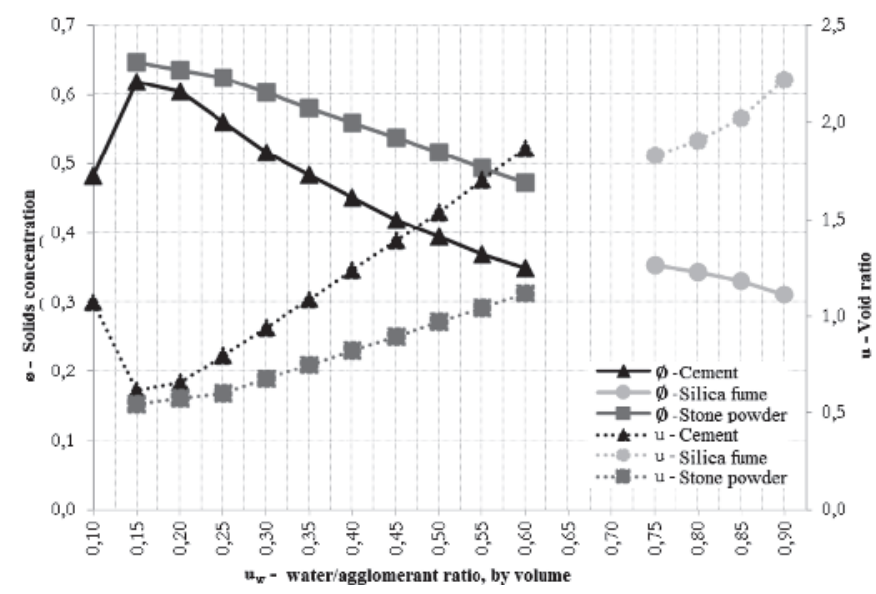

\section{Figure 9}

Results of solids concentration of pastes produced with Portland cement, stone powder and silica fume, individually
$2.0 \%$. The need for high additive contents was observed due to the fineness of silica fume and its high specific surface, requiring a large additive amount to flow (greater than 3\%).

It should be noted, however, that the idea of determining an optimum cement substitution content by stone powder is valid only if a possible concrete application is considered. In order for this application to be feasible, it is important that superplasticizer additive content used is not too high, since this will increase the cost of oncretescubic meter, which would make it impossible to use. The maintenance of the additive content within the limits recommended by the manufacturer also contributes to a greater acceptance of the market in the use of this product for concretes. Therefore, it was not used in the tests to determine the superplasticizer saturation point with silica fume, since it would not be feasible to use more than $3 \%$ of this additive in the concrete production.

Therefore, it was decided to fix superplasticizer content in $0.9 \%$ on the total solids mass, being this the second highest value found. It was decided to fix a single content of additive, since the three materials will be part of the same blend. It is known that this chosen path does not guarantee total dispersion of the fine materials in the mixture, because although it will take into account the saturation point of the cement and the stone powder, the additive will not be sufficient to cover all grains surface of given the presence of the silica fume. Soon, there will be agglomerations in the mixtures produced. In spite of this problem, the results obtained represent the packing of the fine particles as it would be found in a real condition, allowing the studied pastes to be used in the future in the production of concretes, including concretes of high resistance, given the presence of the active silica.

\subsection{Density of packaging of thin materials}

The results of solids concentration and voids ratio of fine materials, obtained by [14], are presented in Figure 9. The optimum packing density, with corresponding w/s ratio, is given in Table 4 . Note that the results presented in Table 4 correspond to the maximum solids concentration obtained for each material, according to the shown 


\section{Table 4}

Density of experimental packaging of the studied fine materials

\begin{tabular}{cccc}
\hline Material & $\begin{array}{c}\text { Experimental } \\
\text { packing } \\
\text { density } \\
\text { ( } \phi \text { maximum) }\end{array}$ & $\begin{array}{c}\text { Void ratio } \\
\text { (u minimum) }\end{array}$ & $\begin{array}{c}\text { Ideal ratio } \\
\text { w/s }\end{array}$ \\
\hline Portland & 0.610 & 0.639 & 0.15 \\
Cement & 0.655 & 0.527 & 0.17 \\
Stone powder & 0.354 & 1.828 & 0.75 \\
Silica fume & 0
\end{tabular}

in Figure 9, this value is equal to the experimental packing density. The minimum void and $\mathrm{w} / \mathrm{s}$ ratio are also corresponding to the maximum solids concentration.

Analyzing studied fine materials individually, Table 4 shows the inverse relation between packing density and void ratio. In cement case, the packing density of 0.610 corresponds to a void ratio of 0.639 , which is the minimum void ratio found with the $w / s$ ratio of 0.15 . For values below 0.15 , the water amount in blend was insufficient to wet all of the component particles. However, for values above 0.15 , excess water is observed between particles, reducing solids concentration and increasing voids ratio as the $\mathrm{w} / \mathrm{s}$ ratio increases. That is, above the ideal water content, particles get distant, increasing the amount of air between them and, consequently, reducing the solids concentration, measured by the apparent density. The same reasoning can be applied to stone powder, which obtained the packing density of 0.655 , corresponding to a void ratio of 0.527 and a w/s ratio equal to 0.17 .

However, a packing density of 0.354 is observed analyzing silica fume, inferior to others. Void ratio 1.828 is higher than others ratios found. The higher void ratio found indicates that are more voids than solids in silica fume mixture, probably due to the high formation of agglomerates. In addition, the curves for silica fume (Figure 9 ) highlight the need for a higher amount of water $(w / s)$ to obtain packing density. This can be explained by silica fume high fineness. Water demand is a function of particles specific surface: how larger the particles specific surface is, more water will be required to wet them. Considering that packing density is obtained when all system particles are wet, it is natural that the amount of water demanded by silica fume exceeds that demanded by cement and stone powder. Moreover, in silica fume agglomerates particles there is also trapped air, which leads to a high void ratio [33].

Comparing Table 4 materials, it was observed that the higher packing density (and consequently the lowest voids ratio) was obtained for stone powder. Silica fume gain the lowest packing density among studied materials. Portland cement presented intermediate values among these three materials. These differences in packing density were already expected due to the difference in average materials diameter. Table 1 show that stone powder has the largest average diameter between fine materials (more than 5 times of Portland cement diameter and 200 times of silica fume). Consequently, stone powder has less agglomeration between particles, so it is the material with less voids and higher packing density, among the three fine materials studied. Comparing cement and stone powder, the stone powder has a wider particle size range, so smaller grains fill the voids left by larger grains, successively. With the same reasoning, silica fume has a packing density lower than the others materials, the ratio between superficial area and volume is bigger in small particles, which causes attraction forces between grains been dominant, favoring agglomerates formation [12; 34], resulting in increased voids between particles and, consequently, reduction in packaging density.

\subsection{Optimum ratio between Portland cement and stone powder}

The determination of optimum ratio between Portland cement and stone powder was done using CPM model [16] and, in parallel, by means of experimental method proposed by [14]. Figure 10 presents results of solids concentration and voids ratio for pastes produced with Portland cement, stone powder and silica fume, according to [14]. The ratio of silica fume was set at $11 \%$ by volume. The proportion of stone powder varied by $0,7,14$ and $21 \%$ by volume, instead of cement. It is emphasized that the maximum solids concentration of each paste represents experimental blend packing density. This value is then compared with the packing density obtained by CPM model [16] in Figure 11.

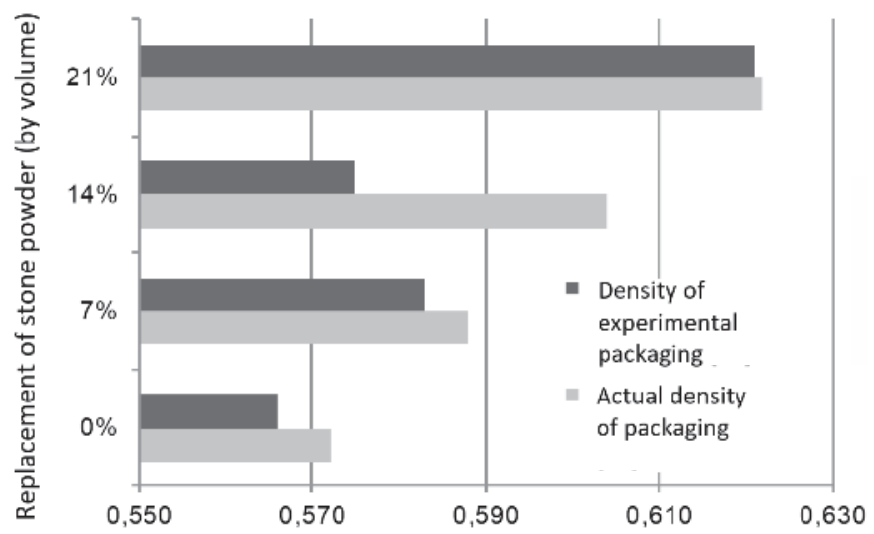

Figure 11

Experimental and analytical packing density of each cement replacement content by stone powder 
Table 5

Evaluation of excess water

\begin{tabular}{|c|c|c|c|c|c|c|c|}
\hline \multirow[b]{2}{*}{ Concrete } & \multicolumn{5}{|c|}{ Consumption of material for consistency analysis } & \multirow[b]{2}{*}{$\begin{array}{l}\text { Water consumption for maximum } \\
\text { concentration of solids } \\
\qquad\left(\mathrm{m}^{3}\right)\end{array}$} & \multirow[b]{2}{*}{$\begin{array}{l}\text { Excess } \\
\text { water } \\
\left(\mathrm{m}^{3}\right)\end{array}$} \\
\hline & $\begin{array}{c}\text { Cement } \\
\left(\mathrm{m}^{3}\right)\end{array}$ & $\begin{array}{l}\text { Silica } \\
\text { fume } \\
\left(\mathrm{m}^{3}\right)\end{array}$ & $\begin{array}{c}\text { Stone } \\
\text { powder } \\
\left(\mathrm{m}^{3}\right)\end{array}$ & $\begin{array}{c}\mathrm{SP} \\
\left(\mathrm{m}^{3}\right)\end{array}$ & $\begin{array}{l}\text { Water } \\
\left(\mathrm{m}^{3}\right)\end{array}$ & & \\
\hline $0 \%$ & 0.462 & 0.057 & 0.000 & 0.013 & 0.467 & 0.39 & 0.08 \\
\hline $7 \%$ & 0.430 & 0.057 & 0.035 & 0.013 & 0.465 & 0.31 & 0.16 \\
\hline $14 \%$ & 0.398 & 0.057 & 0.069 & 0.013 & 0.463 & 0.39 & 0.08 \\
\hline $21 \%$ & 0.366 & 0.056 & 0.103 & 0.013 & 0.461 & 0.31 & 0.15 \\
\hline
\end{tabular}

It can be seen from Figure 11 that the proportion with the greatest substitution of Portland cement by the stone powder, equal to $21 \%$ by volume, was the one that obtained the highest packing density by CPM model and experimental method. This is a very positive result, since the replacement of cement by stone powder in high proportions presents economic and environmental advantages. It is also verified that the theoretical and experimental values of packing density are very close, with a maximum difference of $4.8 \%$ in case of $14 \%$ of stone powder replacing cement. This demonstrates CPM model [16] effectiveness when applied to cement pastes.

When comparing the results of Figure 11 with those presented previously in Table 4, it is verified that through theoretical model the packing densities were obtained for three materials (cement, stone powder and silica fume) blend, superior to those obtained for each material. This shows that complementary granulometries lead to higher packaging densities. However, comparing experimental blends densities and individual materials densities, can be noted that stone powder obtained a higher packing density than blends. This is due to a wider granulometric distribution of the same, helping fill voids.

\subsection{Influence of excess water on the consistency of pastes}

The composition of pastes produced with Portland cement replacement by stone powder and evaluated through Kantro mini cone are presented in Table 5, as well as the water consumption for solids maximum concentration and excess of water for each paste.

\section{Excess water $X$ flow}

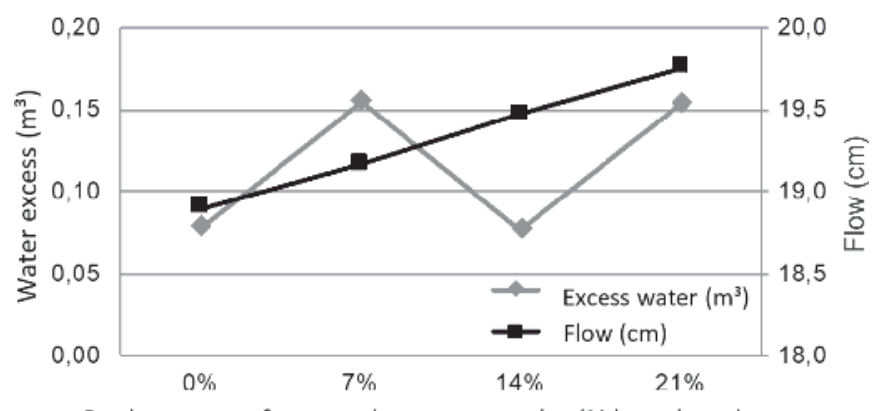

Replacement of cement by stone powder (\% by volume)

\section{Figure 12}

Relation between excess water and the consistency of the pastes
The relation between excess water and pastes consistency for the four Portland cement substitution contents by stone powder is presented in Figure 12.

It is observed in Figure 12 that fluidity obtained in Kantro mini cone grew with stone powder addition content. With volume of paste kept constant, the use of materials with different granulometry increased the excess water content. As excess water is responsible for paste lubrication, a higher packing cementitious density materials for a given volume of water improves the flowability. As a consequence, there is a better dispersion between particles and an increase in blend workability [35; 36].

Note that contents excess water $0 \%$ and $14 \%$ of stone powder were lower than $7 \%$ and $21 \%$. The paste produced with $0 \%$ of stone powder presented higher amounts of fines (Portland cement and silica fume), since it does not present the stone powder in its composition. It also presented the lowest fluidity among the pastes. This is due to higher specific surface area of fines, the greater amount in this mixture, which raises the water demand needed to wet particles, so that water is not available to assist in blend fluidity. In addition, the amount of superplasticizer was constant in all mixtures, and probably not sufficient to promote complete particles dispersion in that fines content. When stone powder is incorporated into pastes at the rate of $7 \%$ cement replacement by powder, the percentage of fines in mixture is reduced, and consequently particles specific surface area also reduces. This reduces the demand for water needed to wet the particles, which leaves more water available to promote fluidity. Moreover, the higher packaging density of this paste means that volume of water needed to fill voids between grains is smaller, which also contributes to increase the excess of water. However, paste produced with a $14 \%$ substitution of cement by powder presented lower excess of water compared to $7 \%$ of substitution. Therefore, this content had more voids and demanded more water. What had already been observed in experimental packing density (Figure 11).

Also in Figure 11 and Figure 12, it was observed that the 21\% substitution content obtained the highest packing density, experimental and analytical, and had a water excess greater than the $14 \%$ content, as expected. In this case, packing density is higher, resulting a lower water demand and higher workability.

\section{Conclusion}

From experimental program developed and results obtained, following conclusions can be drawn:

- For Portland cement the ideal additive content is $0.9 \%$ and for 
de stone powder the ideal additive content is $0.6 \%$ relative to the mass of fine materials. For silica fume it is not plausible to perform this test, since it would demand SP content much higher than the other materials and that recommended by the manufacturer.

- The stone powder presented the highest value of packing density, when the materials were analyzed separately, due to a wider particle size distribution.

- According to results obtained by applying CPM [16] and experimental method [14], paste composition with $68 \%$ Portland cement, $21 \%$ stone powder and $11 \%$ silica fume by volume was which had the highest particle packing density. This corresponds to values of $74 \%$ Portland cement, $18 \%$ stone powder and $8 \%$ silica fume, by mass.

- Due to the high fineness of silica fume particles, the packing density of this material was much lower than cement and stone powder. This was due to the higher specific surface area of silica fume, leading to the need for more water to wet it. In addition, finer particles are more susceptible to agglomeration effects. Because in small particles the surface area is bigger than volume. This causes that forces of attraction are dominant before gravitational forces. Thus, how finer particles are, the greater agglomeration effect. Among silica fume agglomerates particles there is also entrapped air, leading to a high void ratio. As superplasticizer content was constant in determining the packing density, it is natural that it has been less efficient in providing individual dispersion of silica fume particles, since silica fume is much thinner than cement and stone powder

- The analytical packing density values for materials mixtures, by CPM model [16], were higher than the experimental packaging density values obtained for each material. It demonstrates that complementary granulometries, or a larger amplitude of grain size without set, lead to higher packaging densities.

- Pastes flowability increased with the raise of stone powder content. Excess water is responsible for paste lubrication, so a higher packing density for a given volume of water, improves fluidity.

- The higher cement substitution for stone powder, $21 \%$ by volume and $18 \%$ by mass, obtained the highest packaging density, experimental and analytical, and the highest workability, allowing economic and environmental advantages.

\section{Acknowledgments}

To the companies Itambé, Grace and Concrebrás, who kindly provided all the necessary materials for the production of the briefcases studied. To Post-Graduation Program in Civil Construction Engineering (PPGECC) of Paraná Federal University for the opportunity to elaborate the present research.

\section{References}

[1] Barbosa, M. T. G.; Coura, C. V. G.; Mendes, L. D. O. Estudo sobre a areia artificial em substituição à natural para confecção de concreto. Revista Ambiente Construído, vol. 8, no. 4, p. 51-60, 2008.

[2] Balapgol, B.; Kulkarni, S. A.; Bajoria K. M. Strength and durability of concrete with crushed sand. In 27th Conf. Our
World Concr. Struct. 29 - 30 August 2002, Singapore, vol. 158, no. SB3, p. 191-199, 2002.

[3] Gonçalves, J. P.; Tavares, L. M.; Toledo Filho, R. D.; Fairbairn, E. M. R.; Cunha, E. R. Comparison of natural and manufactured fine aggregates in cement mortars. Cement and Concrete Research, vol. 37, no. 6, p. 924-932, 2007.

[4] Campos, H. F.; Marques Filho, J.; Oliveira, D. R. B. Determinação do teor ótimo de superplastificante na pasta de cimento Portland produzida com substituição parcial do aglomerante pelo pó de pedra existente nas areias artificiais. Anais do $57^{\circ}$ Congresso Brasileiro do Concreto, p. 1-13, 2015.

[5] Jonh, V. M. Concreto Sustentável. In: ISAIA, G. C. Concreto: Ciência e Tecnologia. São Paulo: Ibracon, 2011. v. 2.

[6] Campos, H. F. Concreto de alta resistência utilizando pó de pedra como substituição parcial do Cimento Portland: Estudo experimental. Dissertação (Mestrado em Engenharia de Construção Civil), Universidade Federal do Paraná (UFPR), Curitiba, 2015.

[7] Almeida, S. L. M.; Silva, V. Areia artificial : uma alternativa econômica e ambiental para o mercado nacional de agregados. In: II SUFFIB - Seminário: O Uso da Fração Fina da Britagem. São Paulo, p. 10, 2005.

[8] Andriolo, F. R. Usos e abusos do pó de pedra em diversos tipos de concreto. In: II SUFFIB - Seminário: O Uso da Fração Fina da Britagem. São Paulo, p. 1, 2005.

[9] Ji, T.; Chen, C. Y.; Zhuang, Y. Z.; Chen, J. F. A mix proportion design method of manufactured sand concrete based on minimum paste theory. Construction and Building Materials, vol. 44, p. 422-426, 2013.

[10] Berndt, M. L. Influence of concrete mix design on $\mathrm{CO}_{2}$ emissions for large wind turbine foundations. Renew. Energy, vol. 83, p. 608-614, 2015.

[11] Relatório anual do Sindicato Nacional da Indústria do Cimento, 2013.

[12] De Castro, A. L.; Pandolfelli, V. C. Revisão: conceitos de dispersão e empacotamento de partículas para a produção de concretos especiais aplicados na construção civil. Cerâmica, vol. 55, no. 333, p. 18-32, 2009.

[13] Damineli, B. L. Conceitos para formulação de concretos com baixo consumo de ligantes: controle reológico, empacotamento e dispersão de partículas. Tese (Doutorado em Engenharia), Escola Politécnica da Universidade de São Paulo, São Paulo. 2013.

[14] Wong, H. H. C.; Kwan, A. K. H. Packing density of cementitious materials: part 1-measurement using a wet packing method. Materials and Structures, vol. 41, no. 4, p. 689-701, 2008.

[15] Fennis, S. M.; Walraven, J. C. Using particle packing technology for sustainable concrete mixture design. Heron., vol. 57(2), p. 73-101, 2012.

[16] De Larrard, F. Concrete mixture proportioning: A Scientific Approach. Modern Concrete Technology Series, v. 9. E \& FN SPON, London. 1999.

[17] Klein, N. S. El rol físico del agua en mezclas de cemento Portland. Tese (Doutorado em Engenharia Civil), Universitat Politècnica de Catalunya, 2012. 
[18] Li, L. G.; Kwan, A. K. H. Concrete mix design based on water film thickness and paste film thickness. Cement and Concrete Composites, vol. 39, p. 33-42, 2013.

[19] Fennis, S. M. Design of ecological concrete by particle packing optimization. Tese (Doutorado em Engenharia Civil), Delft University of Technology, Holanda, 2011.

[20] AMERICAN CONCRETE INSTITUTE, ACI. Report on HighStrength Concrete - ACI Committee 363, 2002.

[21] Khan, M. I. Isoresponses for strength, permeability and porosity of high performance mortar. Building and Environment, vol. 38, p. 1051-1056, 2003.

[22] Mazloom, M.; Ramezanianpour, A. A.; Brooks, J. Effect of silica fume on mechanical properties of high-strength concrete. Cement and Concrete Composites, vol. 26, p. 347-357, 2004.

[23] Wong, H. S.; Abdul Razak, H. Efficiency of calcined kaolin and silica fume as cement replacement material for strength performance. Cement and Concrete Research, vol. 35, p. 696-702, 2005.

[24] Wongkeo, W.; Thongsanitgarn, P.; Ngamjarurojana, A.; Chaipanich, A. Compressive strength and chloride resistance of self-compacting concrete containing high level fly ash and silica fume. Materials and Design, vol. 64, p. 261-269, 2014.

[25] Mendes, S. Estudo experimental de concreto de alto desempenho utilizando agregados graúdos disponíveis na região metropolitana de Curitiba. Dissertação. (Mestrado em Construção Civil), Universidade Federal do Paraná (UFPR), Curitiba, 2002.

[26] ASSOCIAÇÃO BRASILEIRA DE NORMAS TÉCNICAS. Cimento Portland de alta resistência inicial. - NBR 5733, Rio de Janeiro, 1991.

[27] ASSOCIAÇÃO BRASILEIRA DE NORMAS TÉCNICAS. Aditivos para concreto de cimento Portland. - NBR 11768, Rio de Janeiro, 2011.

[28] Kantro, D. Influence of Water-Reducing Admixtures on Properties of Cement Paste: A Miniature Slump Test. Cement and Concrete Aggregates, vol. 2, p. 95-102, 1980.

[29] ASSOCIAÇÃO BRASILEIRA DE NORMAS TÉCNICAS. Calda de cimento para injeção. - NBR 7681, Rio de Janeiro, 2013.

[30] Campos, H. F.; Marques Filho, J. Análise da trabalhabilidade e da resistência à compressão de argamassas produzidas com substituições parciais da areia artificial por pó de pedra. Anais do $57^{\circ}$ Congresso Brasileiro do Concreto, p. 1-16, 2015.

[31] Polucha, A. Estudo experimental de concreto auto adensável utilizando areia $100 \%$ artificial e fíler calcário como substituição parcial do cimento Portland. Dissertação (Mestrado em Engenharia de Construção Civil), Universidade Federal do Paraná (UFPR), Curitiba, 2016.

[32] Hoffmann, L. Efeitos da adição de materiais pulverulentos proveniente da britagem de rochas na resistência de concretos convencionais. Dissertação (Mestrado em Engenharia de Construção Civil), Universidade Federal do Paraná (UFPR), Curitiba, 2015.

[33] Hermann, A.; Langaro, E. Lopes da Silva, S. H.; Klein, N. S. Empacotamento de partículas de cimento e sílica ativa em pastas pelo uso de modelo analítico. Revista Ibracon Estruturas e Materiais, vol. 9, no. 1, p. 48-65, 2016.

[34] Klein, N. S.; Cavalaro, S.; Aguado, A.; Segura, I.; Toralles, B. The wetting water in cement-based materials: Modeling and experimental validation. Construction and Building Materials, vol. 121, p. 34-43, 2016.

[35] Wong, H. H. C.; Kwan, A. K. H. Packing density : a key concept for mix design of high performance concrete. In: Materials Science and Technology in Engineering Conference (MaSTEC), pp. 1-15, 2005.

[36] Yu, A. B.; Feng, C. L.;. Zou, R. P.; Yang, R. Y. On the relationship between porosity and interparticle force. Powder Technology, vol. 130, no. 1-3, p. 70-76, 2003.

[37] Wong, H. H. C.; Kwan, A. K. H. Packing density of cementitious materials: part 2-packing and flow of OPC + PFA + CSF. Materials and Structures, vol. 41, no. 4, p. 773-84, 2008. 